\title{
Cerebral and cerebellar ADC values during a migraine attack
}

Bumin Degirmenci • Mehmet Yaman • Alpay Haktanir •

Ramazan Albayrak • Murat Acar • Aylin Yucel

Published online: 17 February 2007

(C) Springer-Verlag 2007

\section{Neuroradiology DOI 10.1007/s00234-006-0201-1}

One of the authors was omitted:

Aylin Yucel

Department of Radiology, Faculty of Medicine,

Kocatepe University, Afyon, Turkey

The online version of the original article can be found under doi:10.1007/s00234-006-0201-1.

B. Degirmenci $(\bowtie) \cdot$ A. Haktanir $\cdot$ R. Albayrak $\cdot$ M. Acar $\cdot$

A. Yucel

Department of Radiology, Faculty of Medicine,

University of Kocatepe,

03200 Afyon, Turkey

e-mail: bdegirmenci@aku.edu.tr

M. Yaman

Department of Neurology, Faculty of Medicine,

University of Kocatepe,

Afyon, Turkey 